\title{
Synthesis and characterization of novel 1,6-dihydropyrimidine derivatives for their pharmacological properties
}

\author{
Basavaraj Padmashali ${ }^{*}$, Ballekere Nanjundaswamy Chidananda ${ }^{2}$, Banuprakash Govindappa ${ }^{3}$, Siddesh M. Basavaraj ${ }^{4}$, \\ Sandeep Chandrashekharappa ${ }^{2 *}$, Katharigatta N. Venugopala ${ }^{5,6}$ \\ ${ }^{1}$ Department of Chemistry, School of Basic Sciences, Rani Channamma University, Belagavi, India. \\ ${ }^{2}$ Department of Chemistry, Sahyadri Science College (Kuvempu University), Shimoga, India. \\ ${ }^{3}$ Department of Chemistry, SJB Institute of Technology, Bangalore, India. \\ ${ }^{4}$ Department of Chemistry, KLE College of Engineering and Technology, Chikodi, Belagavi, India. \\ ${ }^{5}$ Department of Pharmaceutical Sciences, College of Clinical Pharmacy, King Faisal University, Al-Ahsa, Kingdom of Saudi Arabia. \\ ${ }^{6}$ Department of Biotechnology and Food Technology, Faculty of Applied Science, Durban University of Technology, Durban, South Africa.
}

\begin{tabular}{|c|c|}
\hline ARTICLE INFO & ABSTRACT \\
\hline $\begin{array}{l}\text { Received on: 06/02/2019 } \\
\text { Accepted on: 04/04/2019 } \\
\text { Available online: } 08 / 05 / 2019\end{array}$ & $\begin{array}{l}\text { The present research work involves the use of commercially available thiophene-2-carbaldehyde as a starting material } \\
\text { to construct novel pyrimidine compounds. Synthesis of pyrimidine derivatives has been done by the trimolecular } \\
\text { Biginelli condensation reaction, which involves the use of thiophene-2-carbaldehyde with cyano ethylacetate and } \\
\text { thiourea to yield 4-oxo-6-(thiophen-2-yl)-2-thioxo-1,2,3,4-tetrahydropyrimidine-5-carbonitrile (1). The intermediate } 1\end{array}$ \\
\hline $\begin{array}{l}\text { Key words: } \\
\text { Substituted } \\
\text { 1,6-dihydropyrimidine, } \\
\text { synthesis, antibacterial, } \\
\text { antifungal, analgesic. }\end{array}$ & $\begin{array}{l}\text { was methylated using methyl iodide and } \mathrm{K}_{2} \mathrm{CO}_{3} \text { in dimethylformamide (DMF) which afforded dimethylated derivative } \\
\text { 1-methyl-2-(methylthio)-6-oxo-4-(thiophen-2-yl)-1,6-dihydropyrimidine-5-carbonitrile (2). The intermediate } \\
\text { compound } 2 \text { when refluxed with hydrazine hydrate in ethanol as a solvent led to the formation of the parent compound } \\
\text { 2-hydrazineyl-1-methyl-6-oxo-4-(thiophen-2-yl)-1,6-dihydropyrimidine-5-carbonitrile (3), the parent compound } 3 \\
\text { was used for the synthesis of carboxamides of } N^{\prime} \text {-(5-cyano-1-methyl-6-oxo-4-(thiophen-2-yl)-1,6-dihydropyrimidin- } \\
\text { 2-yl)substituted benzohydrazide (4a-d) and Schiff bases of }(E)-2-(2 \text {-substituted benzylidenehydrazineyl)-1-methyl- } \\
\text { 6-oxo-4-(thiophen-2-yl)-1,6-dihydropyrimidine-5-carbonitrile (5a-g). Selected title compounds are screened for } \\
\text { antibacterial, analgesic, and antifungal activities. }\end{array}$ \\
\hline
\end{tabular}

\section{INTRODUCTION}

Heterocyclic compounds play an important roles in biological and pharmaceutical process. As several drug molecules contain heterocycles as a core structure, great efforts have been made to develop improved synthetic methods for this structure (Chandrashekharappa et al., 2018a; 2018b; Mallikarjuna et al., 2016; Nagesh et al., 2014; Sandeep et al., 2013a; 2013b; 2014; 2016a;

\footnotetext{
*Corresponding Author

Basavaraj Padmashali, Department of Chemistry, School of Basic Sciences, Rani Channamma University, Belagavi, India.

E-mail: basavarajpadmashali@yahoo.com;

Sandeep Chandrashekharappa, Department of Chemistry, Sahyadri

Science College, Kuvempu University, Shimoga, India.

E-mail: Sandeep_m7@ rediffmail.com
}

2016b; Siddesh et al., 2014a). Among all heterocycles, pyrimidinebased heterocycles are more interesting in biological applications (Bairagi et al., 2018; Dharma Rao et al., 2017; Devi et al., 2009; Siddesh et al., 2013; Siddesh et al., 2014a; Thriveni et al., 2014; Venugopala et al., 2014). Pyrimidines linked to thiopheno moiety has been reported in the literature for many years (Ram et al., 1987; Ramesh and Bhalgat, 2011). They have been found to possess a wide spectrum of biological activities (Ghith et al., 2017; Noravyan et al., 2012; Wu, 2012), and many of them have been used as drugs in the market (Shishoo et al., 2009), and some of the structures of active pharmaceutical ingredients are highlighted in Figure 1.

The above observations revealed the importance of thienopyrimidine derivatives for various pharmacological properties, such as anticancer (Bugge et al., 2016; Ghith et al., 2017; Ravez et al., 2015; Teo et al., 2015; Yong et al., 2015; Zhang et al., 2015), antiviral (Kankanala et al., 2017), antidiabetic 


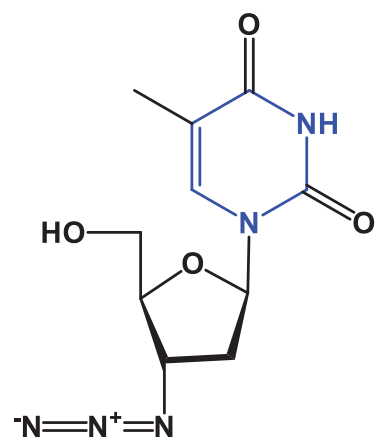<smiles>O=C1NCC(F)C(=O)N1</smiles>

5-Fluorouracil (anticancer)<smiles>CCc1nc(N)nc(N)c1-c1ccc(Cl)cc1</smiles>

Pyrimethamine (antimalarial)

Zidovudine (Anti-HIV drug)<smiles>Nc1cc(N2CCCCC2)nc(N)n1</smiles>

Minoxidil (antihypertensive)

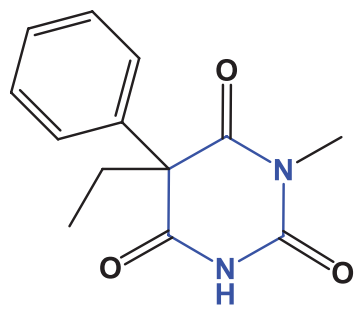

Methylphenobarbital (anticonvulsant)

Figure 1. Chemical structure of active pharmaceutical ingredients having pyrimidine pharmacophore.

(Klossowski et al., 2017), antimicrobial (Aruna Kumari et al., 2017; Bari and Haswani, 2017; Joshi et al., 2011; Ortikov et al., 2017), antitubercular (Borate et al., 2016; Chandrashekharappa et al., 2019; Pisal et al., 2017; Rosado et al., 2017; Srnivasula et al., 2016; Venugopala et al., 2013; 2016), antiulcer (Amr et al., 2016), and immunosuppressive agents (Zhang et al., 2017). Synthesis of these molecular analogues is worth to get novel pharmacologically active leads. Encouraged by the research findings on pharmacological properties of thienopyrimidines, in this work, we have undertaken the synthesis of pyrimidine derivative linked to thiophene moieties $(\mathbf{4 a}-\mathbf{d})$ and $(\mathbf{5 a}-\mathbf{g})$. The sequence of reactions carried out to achieve the title compounds $(\mathbf{4 a}-\mathbf{d})$ and $(\mathbf{5 a}-\mathbf{g})$ is depicted in Scheme 1.

\section{MATERIALS AND METHODS}

\section{Chemistry}

All the chemicals and solvents used were of AR grade and procured from Sigma-Aldrich, India. The Scheme 1 chemical reactions were carried out under a nitrogen atmosphere using a dry solvent. The progress of the reaction was monitored by thin layer chromatography (TLC). TLC was performed on Merck silica gel on TLC aluminum foil with ethyl acetate and hexane as the solvent system and visualization in a UV chamber. IR spectra were recorded on Thermo scientific Fourier-transform infrared spectroscopy (FT-IR) spectrophotometer, and ${ }^{1} \mathrm{H}$ Nuclear magnetic resonance (NMR) spectra were recorded at ambient temperature using dimethyl sulfoxide (DMSO) and $\mathrm{CDCl}_{3}$ as a solvent using Bruker AV 800 spectrometer. The chemical shifts are expressed in $\delta \mathrm{ppm}$ and were reference with tetramethyl silane. The peak multiplicities were specified as follows: s, singlet; d, doublet; t, triplet; q, quartet; and m, multiplet. Liquid chromatography-mass spectrometry (LC-MS) were performed on a Jeol JMS-D 300 mass spectrometer operating at $70 \mathrm{eV}$. Elemental analysis was performed on a Thermo Finnigan FLASH FA 1112 CHN analyzer.

General procedure for the synthesis of $N^{\prime}$-(5-cyano-1methyl-6-oxo-4-(thiophen-2-yl)-1,6-dihydropyrimidin-2-yl) benzohydrazide (4a)

A mixture of 2-hydrazineyl-1-methyl-6-oxo-4(thiophen-2-yl)-1,6-dihydropyrimidine-5-carbonitrile (3) (2.49 g, $0.01 \mathrm{~mol})$, acetyl chloride $(1.40 \mathrm{ml}, 0.01 \mathrm{~mol})$ in acetic acid $(20 \mathrm{ml})$ was refluxed for 4 hours. The completion of the reaction was monitored by TLC. After reaction completion, the resulting reaction medium was poured into the ice cold water, stirred well, the solid obtained was filtered and washed thoroughly with water. The crude compound was purified through recrystallization in ethyl alcohol afforded $2.13 \mathrm{~g}(60 \%)$ of $N^{\prime}$-[5-cyano-1-methyl-6oxo-4-(thiophen-2-yl)-1,6-dihydropyrimidin-2-yl]acetohydrazide (4a). Similarly, the remaining compounds $\mathbf{4 b}, \mathbf{4 c}$, and $\mathbf{4 d}$ were prepared by following a similar procedure. FT-IR $(\mathrm{KBr}) v\left(\mathrm{~cm}^{-1}\right)$ : 3,074 (NH), $2216(\mathrm{CN}), 1,679(\mathrm{C}=\mathrm{O}) ;{ }^{1} \mathrm{H}$ NMR $\delta=8.25(\mathrm{NH})$, 7.3-8.3 (m, 3H, ArH), 4.0 (s, 1H, NH), 2.3 (s, 1H, NH), 3.5 (s, $\left.3 \mathrm{H},-\mathrm{NCH}_{3}\right), 2.6\left(\mathrm{~s}, 3 \mathrm{H}, \mathrm{COCH}_{3}\right)$; Elemental analysis calculated for $\mathrm{C}_{12} \mathrm{H}_{11} \mathrm{~N}_{5} \mathrm{O}_{2} \mathrm{~S}$ : C, 49.77; H, 3.80; N, 24.19; Found: C, 49.73; H, 3.76; N, 24.15; LC-MS: $m / z=290.3(\mathrm{M}+1)$.

$N^{\prime}-$ [5-Cyan o-1 - meth y l-6-ox 0-4-(thiophen-2-yl)-1,6dihydropyrimidin-2-yl] benzohydrazide (4b)

FT-IR $(\mathrm{KBr}) v\left(\mathrm{~cm}^{-1}\right): 3,318(\mathrm{NH}), 2,236(\mathrm{CN}), 1,690$ $(\mathrm{C}=\mathrm{O})$; Elemental analysis calculated for $\mathrm{C}_{17} \mathrm{H}_{13} \mathrm{~N}_{5} \mathrm{O}_{2} \mathrm{~S}$ : C, 58.11; 
<smiles>N#Cc1c(-c2cccs2)[nH]c(=S)[nH]c1=O</smiles><smiles>[R]C(=O)NNc1nc(-c2cccs2)c(C#N)c(=O)n1C</smiles>

4a-d

$\mathbf{R}=\mathrm{CH}_{3}, \mathrm{C}_{6} \mathrm{H}_{5}$, furyl, $\mathrm{C}_{6} \mathrm{H}_{5} \mathrm{CH}_{2}$<smiles>C=C</smiles>

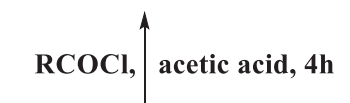<smiles>Cc1nc(-c2cccs2)c(C#N)c(=O)[nH]1</smiles>

1

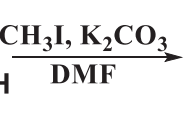<smiles>CCCNNCSc1nc(-c2cccs2)c(C#N)c(=O)n1C</smiles><smiles>Cn1c(NN)nc(-c2cccs2)c(C#N)c1=O</smiles>

3

R-CHO, ethanol, $12 \mathrm{~h}$

$\downarrow$<smiles>[R]C=NNc1nc(-c2cccs2)c(C#N)c(=O)n1C</smiles>

$\mathrm{R}=\mathrm{C}_{6} \mathrm{H}_{5}, 2-\mathrm{OCH}_{3}-\mathrm{C}_{6} \mathrm{H}_{4}$, thienyl, 4-Cl- $\mathrm{C}_{6} \mathrm{H}_{4}, 2-\mathrm{OH}, \mathrm{C}_{6} \mathrm{H}_{4}$, furyl, 4- $\mathrm{NO}_{2}-\mathrm{C}_{6} \mathrm{H}_{4}$

Scheme 1. Synthetic scheme for the construction of N'-(5-cyano-1-methyl-6-oxo-4-(thiophen-2-yl)-1,6-dihydropyrimidin2-yl)substituted benzohydrazide (4a-d) and (E)-2-(2-substituted benzylidenehydrazineyl)-1-methyl-6-oxo-4-(thiophen2-yl)-1,6-dihydropyrimidine-5-carbonitrile (5a-g).

H, 3.73; N, 19.93; Found: C, 58.03; H, 3.64; N, 19.88; LC-MS: $m / z=352.3(\mathrm{M}+1)$.

\section{$N^{\prime}-[5-C y a n 0-1-m e t h y l-6-0 \times 0-4-($ thiophen-2-yl)-1,6- dihydropyrimidin-2-yl]furan-2-carbohydrazide (4c)}

FT-IR $(\mathrm{KBr}) v\left(\mathrm{~cm}^{-1}\right): 3,350(\mathrm{NH}), 2,215(\mathrm{CN}), 1,680$ $(\mathrm{C}=\mathrm{O})$; Elemental analysis calculated for $\mathrm{C}_{15} \mathrm{H}_{11} \mathrm{~N}_{5} \mathrm{O}_{3} \mathrm{~S}$ : C, 52.78; H, 3.25; N, 20.52; Found: C, 52.69; H, 3.18; N, 20.56; LC-MS: $\mathrm{m} / \mathrm{z}=342.3(\mathrm{M}+1)$.

\section{$N^{\prime}$ - [5-Cyano-1-methyl-6-oxo-4-(thiophen-2-yl)-1,6-} dihydropyrimidin-2-yl]-2-phenylacetohydrazide (4d)

FT-IR $(\mathrm{KBr}) v\left(\mathrm{~cm}^{-1}\right): 3,384(\mathrm{NH}), 2,233(\mathrm{CN}), 1,679$ $(\mathrm{C}=\mathrm{O}) ;{ }^{1} \mathrm{H}$ NMR $\delta: 8.56(\mathrm{NH}), 7.89-7.69(\mathrm{~m}, 5 \mathrm{H}, \mathrm{Ar}-\mathrm{H}), 6.25$ (m, 3H-thiophene), 3.99 (2H, benzylic), 3.75 (s, 3H-NCH $)$; Elemental analysis calculated for $\mathrm{C}_{18} \mathrm{H}_{15} \mathrm{~N}_{5} \mathrm{O}_{2} \mathrm{~S}$ : C, 59.17; H, 4.14; N, 19.17; Found: C, 59.07; H, 4.06; N, 19.11; LC-MS: $\mathrm{m} / \mathrm{z}$ $=366.4(\mathrm{M}+1)$.
Synthetic procedure for the preparation of (E)-2-(2benzylidenehydrazineyl)-1-methyl-6-oxo-4-(thiophen-2-yl)1,6-dihydropyrimidine-5-carbonitrile (5a)

The compound 2-hydrazineyl-1-methyl-6-oxo-4(thiophen-2-yl)-1,6-dihydropyrimidine-5-carbonitrile (3) (2.49 g, $0.01 \mathrm{~mol})$ was refluxed with benzaldehyde $(1.06 \mathrm{~g}, 0.01 \mathrm{~mol})$ and a catalytic amount of acetic acid in absolute ethyl alcohol for 12 hours. The completion of the reaction was monitored through TLC, after the completion, the reaction mixture was poured into ice cold water with stirring; the solid obtained was filtered and washed thoroughly with water. The crude product was purified by several trials of recrystallization with rectified spirit afforded the pure 2-[(2E)-2-benzylidenehydrazinyl]-1-methyl-6-oxo-4-(thiophen2-yl)-1,6-dihydropyrimidine-5-carbonitrile (5a) at $2.06 \mathrm{~g}$ (61\%). Similarly, the other Schiff bases $\mathbf{5 b}-\mathbf{g}$ were prepared by following the similar procedure, and their physicochemical parameters are tabulated in Table 1. FT-IR $(\mathrm{KBr}) v\left(\mathrm{~cm}^{-1}\right): 3,113(\mathrm{NH}), 2,224(\mathrm{CN})$, 1,671 $(\mathrm{C}=\mathrm{O}), 1,551(\mathrm{CH}=\mathrm{N}) ;{ }^{1} \mathrm{H}$ NMR $\delta=3.4(\mathrm{~s}, 1 \mathrm{H}, \mathrm{NH}), 9.9(\mathrm{~s}$, 
Table 1. Physicochemical constants of $N^{\prime}$-(5-cyano-1-methyl-6-oxo-4-(thiophen-2-yl)-1,6-dihydropyrimidin-2-yl) substituted benzohydrazide (4a-d) and (E)-2-(2-substitued benzylidenehydrazineyl)-1-methyl-6-oxo-4-(thiophen-2-yl)-1,6dihydropyrimidine-5-carbonitrile $(\mathbf{5 a}-\mathbf{g})$.

\begin{tabular}{|c|c|c|c|c|c|}
\hline Compd code & Mol formulae (Mol mass) & $\mathbf{R}$ & Yield $(\%)^{\mathrm{a}}$ & m.p $\left({ }^{\circ} \mathrm{C}\right)$ & ${ }_{c} \log \mathrm{P}^{\mathrm{b}}$ \\
\hline $4 b$ & $\mathrm{C}_{17} \mathrm{H}_{13} \mathrm{~N}_{5} \mathrm{O}_{2} \mathrm{~S}(351)$ & $\mathrm{C}_{6} \mathrm{H}_{5}$ & 40 & 175 & 0.9042 \\
\hline $4 c$ & $\mathrm{C}_{15} \mathrm{H}_{11} \mathrm{~N}_{5} \mathrm{O}_{3} \mathrm{~S}(341)$ & Furyl & 65 & 189 & 0.0802 \\
\hline $4 d$ & $\mathrm{C}_{18} \mathrm{H}_{15} \mathrm{~N}_{5} \mathrm{O}_{2} \mathrm{~S}(365)$ & $\mathrm{C}_{6} \mathrm{H}_{5} \mathrm{CH}_{2}$ & 38 & 203 & 1.3232 \\
\hline $5 c$ & $\mathrm{C}_{15} \mathrm{H}_{11} \mathrm{~N}_{5} \mathrm{OS}_{2}(341)$ & Thienyl & 35 & 193 & 2.5425 \\
\hline $5 d$ & $\mathrm{C}_{17} \mathrm{H}_{12} \mathrm{ClN}_{5} \mathrm{OS}(369)$ & 4- $\mathrm{Cl}, \mathrm{C}_{6} \mathrm{H}_{4}$ & 50 & 228 & 3.5208 \\
\hline $5 e$ & $\mathrm{C}_{17} \mathrm{H}_{13} \mathrm{~N}_{5} \mathrm{O}_{2} \mathrm{~S}(351)$ & 2-OH, $\mathrm{C}_{6} \mathrm{H}_{4}$ & 42 & 213 & 3.4032 \\
\hline
\end{tabular}

${ }^{\mathrm{a} C}$ Compounds purification by recrystallization method using ethanol as solvent.

${ }^{\mathrm{b}} \mathrm{C} \log P$ was calculated using ChemDraw Professional 16.0v.

$1 \mathrm{H}, \mathrm{N}=\mathrm{CH}), 7.1-8.5(\mathrm{~m}, 8 \mathrm{H}, \mathrm{ArH}), 2.1\left(\mathrm{~s}, 3 \mathrm{H}-\mathrm{NCH}_{3}\right)$; Elemental analysis calculated for $\mathrm{C}_{17} \mathrm{H}_{13} \mathrm{~N}_{5} \mathrm{OS}$ : C, 60.88; H, 3.91; N, 20.88; Found C, 60.80; H, 3.83; N, 20.83; LC-MS: $m / z=336(\mathrm{M}+1)$.

2-[(2E)-2-(2-Methoxybenzylidene)hydrazinyl]-1-methyl-6oxo-4-(thiophen-2-yl)-1,6-dihydropyrimidine-5-carbonitrile (5b)

FT-IR $(\mathrm{KBr}) \quad v \quad\left(\mathrm{~cm}^{-1}\right): \quad 3,196 \quad(\mathrm{NH}), 2,223 \quad(\mathrm{CN})$, $1,779(\mathrm{C}=\mathrm{O}), 1662(\mathrm{CH}=\mathrm{N})$; Elemental analysis calculated for $\mathrm{C}_{18} \mathrm{H}_{15} \mathrm{~N}_{5} \mathrm{O}_{2} \mathrm{~S}$ : C, 59.17; H, 4.14; N, 19.17; Found C, 59.07; H, 4.06; N, 19.11; LC-MS: $m / z=366.4(\mathrm{M}+1)$.

1-Methyl-6-oxo-4-(thiophen-2-yl)-2-[(2E)-2-(thiophen2-ylmethylidene) hydrazinyl]-1,6-dihydropyrimidine-5carbonitrile (5c)

FT-IR $(\mathrm{KBr}) v\left(\mathrm{~cm}^{-1}\right): 3,249(\mathrm{NH}), 2,217(\mathrm{CN}), 1,654$ $(\mathrm{C}=\mathrm{O}), 1,549(\mathrm{CH}=\mathrm{N}) ;{ }^{1} \mathrm{H}$ NMR $\delta=8.80(\mathrm{NH}), 8.58(1 \mathrm{H}, \mathrm{N}=\mathrm{CH})$, 7.04-6.29 (m, 6H-thiophenes), 3.82 (s, 3H-NCH $\mathrm{N}_{3}$ Elemental analysis calculated for $\mathrm{C}_{15} \mathrm{H}_{11} \mathrm{~N}_{5} \mathrm{OS}_{2}$ : C, 52.77; H, 3.25; N, 20.51; Found C, 52.68; H, 3.18; N, 20.46; LC-MS: $m / z=342.4(\mathrm{M}+1)$.

2-[(2E)-2-(4-Chlorobenzylidene)hydrazinyl]-1-methyl-6-oxo4-(thiophen-2-yl)-1,6-dihydropyrimidine-5-carbonitrile (5d)

FT-IR $(\mathrm{KBr}) v\left(\mathrm{~cm}^{-1}\right): 3,097(\mathrm{NH}), 2,216(\mathrm{CN}), 1,657$ $(\mathrm{C}=\mathrm{O}), 1,633(\mathrm{CH}=\mathrm{N}) ;{ }^{1} \mathrm{H}$ NMR $\delta=8.79(\mathrm{NH}), 8.65(1 \mathrm{H}, \mathrm{N}=\mathrm{CH})$, 8.01-7.86 (m, 4H, Ar-H), 6.94-6.60 (m, 3H-thiophene), 3.71 (s, $3 \mathrm{H}-\mathrm{NCH}_{3}$ ); Elemental analysis calculated for $\mathrm{C}_{17} \mathrm{H}_{12} \mathrm{ClN}_{5} \mathrm{OS}: \mathrm{C}$, 55.21 ; H, 3.27; N, 18.94; Found C, 55.12; H, 3.20; N, 18.88; LCMS: $m / z=369\left(\mathrm{M}^{+}\right)$.

2-[(2E)-2-(2-Hydroxybenzylidene)hydrazinyl]-1-methyl-6oxo-4-(thiophen-2-yl)-1,6-dihydropyrimidine-5-carbonitrile (5e)

FT-IR $(\mathrm{KBr}) v\left(\mathrm{~cm}^{-1}\right): 3,379(\mathrm{NH}), 2,254(\mathrm{CN}), 1,700$ $(\mathrm{C}=\mathrm{O}), 1,555(\mathrm{CH}=\mathrm{N}) ;{ }^{1} \mathrm{H}$ NMR $\delta=8.78(\mathrm{NH}), 8.66(1 \mathrm{H}, \mathrm{N}=\mathrm{CH})$, 7.99-7.80 (m, 4H, ArH), 6.88-6.70 (m, 3H-thiophene), 3.80 (s, $3 \mathrm{H}-\mathrm{NCH}_{3}$ ); Elemental analysis calculated for $\mathrm{C}_{17} \mathrm{H}_{13} \mathrm{~N}_{5} \mathrm{O}_{2} \mathrm{~S}: \mathrm{C}$,
58.11; H, 3.73; N, 19.93; Found C, 57.86; H, 3.66; N, 19.88; LC-MS: $m / z=352.3(\mathrm{M}+1)$.

2-[(2E)-2-(Furan-2-ylmethylidene)hydrazinyl]-1-methyl-6oxo-4-(thiophen-2-yl)-1,6-dihydropyrimidine-5-carbonitrile (5f)

FT-IR $(\mathrm{KBr}) v\left(\mathrm{~cm}^{-1}\right): 3,378(\mathrm{NH}), 2,266(\mathrm{CN}), 1,689$ $(\mathrm{C}=\mathrm{O}), \quad 1,544 \quad(\mathrm{CH}=\mathrm{N})$; Elemental analysis calculated for $\mathrm{C}_{15} \mathrm{H}_{11} \mathrm{~N}_{5} \mathrm{O}_{2} \mathrm{~S}$ : C, 55.38; H, 3.41; N, 21.53; Found:- C, 55.33; H, 3.39 ; N, 21.51; LC-MS: $m / z=326.3(\mathrm{M}+1)$.

1-Methyl-2-[(2E)-2-(4-nitrobenzylidene)hydrazinyl]-6-oxo-4(thiophen-2-yl)-1,6-dihydropyrimidine-5-carbonitrile (5g)

FT-IR $(\mathrm{KBr}) v\left(\mathrm{~cm}^{-1}\right): 3,368(\mathrm{NH}), 2,256(\mathrm{CN}), 1,670$ $(\mathrm{C}=\mathrm{O}), \quad 1,545 \quad(\mathrm{CH}=\mathrm{N})$; Elemental analysis calculated for $\mathrm{C}_{17} \mathrm{H}_{12} \mathrm{~N}_{6} \mathrm{O}_{3} \mathrm{~S}: \mathrm{C}, 53.68 ; \mathrm{H}, 3.18 ; \mathrm{N}, 22.09$; Found $\mathrm{C}, 53.60 ; \mathrm{H}$, $3.11 ; \mathrm{N}, 22.04$; LC-MS: $m / z=381.3(\mathrm{M}+1)$.

\section{Pharmacology}

Antibacterial activity

The antibacterial activity of the synthesized compounds was performed using a cup plate method (Nagesh et al., 2015) employing Hi-Media agar medium against two Gram-positive bacteria Bacillus subtilis (ATCC 6633) and Staphylococcus aureus (ATCC 25923) and Gram-negative bacteria Escherichia coli (ATCC 35218) and Pseudomonas aeruginosa (ATCC 10145). The antibacterial results of the studied compounds are summarized in Table 2. The tested compounds exhibited slight to moderate antibacterial activity against all microorganisms when compared to the standard compounds.

\section{Antifungal activity}

The antifungal activity (Nagesh et al., 2015) of the test compounds was tested against two different fungal strains, namely, Candida albicans and Aspergillus niger by a filter paper disc technique at 50 and $100 \mu \mathrm{g} / \mathrm{ml}$ concentrations. After 48 hours incubation, the zone of inhibition was measured in 
millimeter. Griseofulvin was used as the standard drug and dimethylformamide as a control. The antifungal results are tabulated in Table 3.

\section{Analgesic activity}

Analgesic activity of the test compounds was tested by an acetic-acid-induced writhing method using Albino mice of either sex (20-30 g) (Siddesh et al., 2014b). A 0.6\% Acetic acid solution was used to induce writhing in mice. Eleven groups of animals were prepared with six animals in each. The analgesic response was assessed by counting the number of abdominal constrictions for 20 minutes starting 3 minutes after the injection of acetic acid solution. The test compounds were administered to group 1-10 at $100 \mathrm{mg} / \mathrm{kg}$ body weight and eleventh group received the standard drug at $100 \mathrm{mg} / \mathrm{kg}$ body weight. After 1 hour, the acetic acid solution was administered intraperitoneally, and a number of abdominal constrictions were documented for 20 minutes starting 3 minutes after the injection of acetic acid solution. The analgesic activity was calculated as the percentage of maximum possible effect, and the results are given in Table 4. Animal ethical clearance to conduct in vivo analgesic activity was obtained from the ethical committee from the institution.

\section{RESULTS AND DISCUSSION}

\section{Chemistry}

In the present work, synthesis of proposed compounds $\quad N^{\prime}$-(5-cyano-1-methyl-6-oxo-4-(thiophen-2-yl)-1,6dihydropyrimidin-2-yl)substituted benzohydrazide (4a-d) and (E)-2-(2-substituted benzylidenehydrazineyl)-1-methyl-6-oxo4-(thiophen-2-yl)-1,6-dihydropyrimidine-5-carbonitrile $\quad(\mathbf{5 a}-\mathbf{g})$ were achieved by exploiting commercially available thiophene2-carbaldehyde as a starting compound. Synthesis of parent compound 2-hydrazineyl-1-methyl-6-oxo-4-(thiophen-2-yl)1,6-dihydropyrimidine-5-carbonitrile (3) is achieved based on the reported procedure (Ram et al., 1987; Ramesh and Bhalgat, 2011). Novel compounds (4b-d) are prepared by following the procedure involved in the synthesis of title compound $N^{\prime}$-[5cyano-1-methyl-6-oxo-4-(thiophen-2-yl)-1,6-dihydropyrimidin2-yl] acetohydrazide (4a) (Ram et al., 1987). Schiff bases of novel title compounds (5a-g) are prepared by refluxing parent compound 2-hydrazineyl-1-methyl-6-oxo-4-(thiophen-2-yl)-1,6dihydropyrimidine-5-carbonitrile (3) with substituted, phenyl, thienyl, and furyl aldehydes in absolute ethanol medium.

Synthesis of 4-oxo-6-(thiophen-2-yl)-2-thioxo-1,2,3,4tetrahydropyrimidine-5-carbonitrile (1) involves the trimolecular

Table 2. Antibacterial activity of test compounds $\mathbf{3 a}, \mathbf{4 a}, \mathbf{4 b}, \mathbf{5 a}, \mathbf{5 b}, \mathbf{5 c}$, and $\mathbf{5} \mathbf{f}$ against Gram-positive and Gram-negative organisms in comparison with controls.

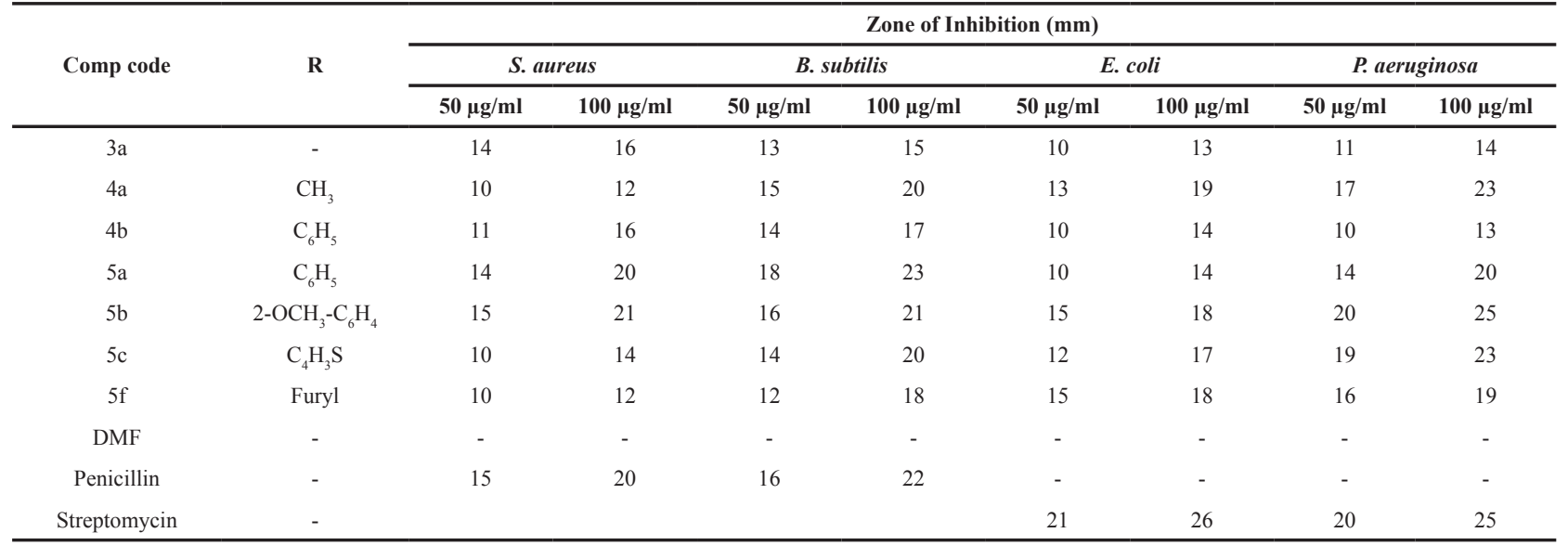

Table 3. Antifungal activity of test compounds $\mathbf{3 a}, \mathbf{4 a}, \mathbf{4 b}, \mathbf{5 a}, \mathbf{5 b}, \mathbf{5} \mathbf{c}$, and $\mathbf{5 f}$ in comparison with controls.

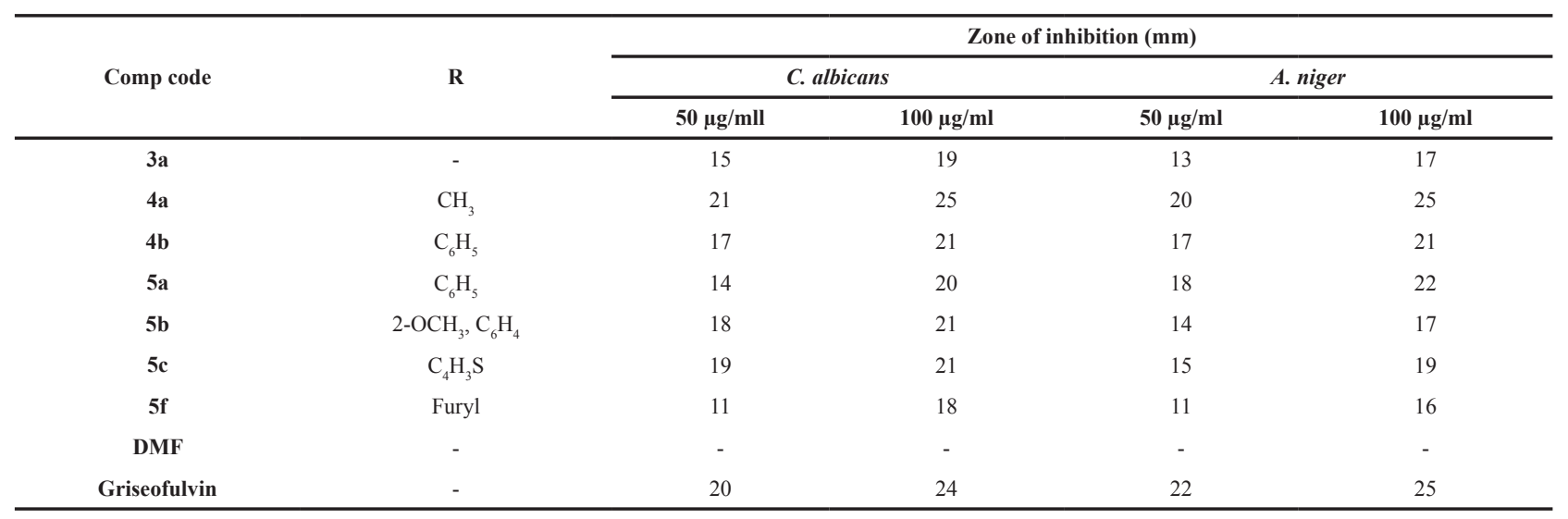


Table 4. Analgesic activity of test compounds $\mathbf{3 a}, \mathbf{4 a}, \mathbf{4 b}, \mathbf{5 a}, \mathbf{5 b}, \mathbf{5 c}$, and $\mathbf{5 f}$ in comparison with controls.

\begin{tabular}{|c|c|c|c|}
\hline Comp code & $\mathbf{R}$ & Mean no. of Writhings \pm SEM & Percentage protection \\
\hline $3 a$ & - & $20.83 \pm 2.43$ & 54.54 \\
\hline $4 a$ & $\mathrm{CH}_{3}$ & $18.42 \pm 1.84$ & 59.80 \\
\hline $4 \mathrm{~b}$ & $\mathrm{C}_{6} \mathrm{H}_{5}$ & $20.84 \pm 2.16$ & 54.52 \\
\hline $5 a$ & $\mathrm{C}_{6} \mathrm{H}_{5}$ & $17.57 \pm 1.69$ & 61.16 \\
\hline $5 b$ & $2-\mathrm{OCH}_{3}, \mathrm{C}_{6} \mathrm{H}_{4}$ & $16.84 \pm 1.54$ & 63.32 \\
\hline $5 c$ & $\mathrm{C}_{4} \mathrm{H}_{3} \mathrm{~S}$ & $18.09 \pm 1.64$ & 60.05 \\
\hline $5 f$ & Furyl & $23.51 \pm 2.94$ & 48.70 \\
\hline Tween 80 & - & $45.83 \pm 3.66$ & - \\
\hline Aspirin & - & $11.99 \pm 1.27$ & 73.83 \\
\hline
\end{tabular}

Biginelli condensation of thiophene-2-carbaldehyde with cyanoethylacetate and thiourea. The compound 1 was methylated using methyl iodide and $\mathrm{K}_{2} \mathrm{CO}_{3}$ in dimethylformamide (DMF) which afforded dimethylated derivative 1-methyl-2-(methylthio)6-oxo-4-(thiophen-2-yl)-1,6-dihydropyrimidine-5-carbonitrile (2). The formation of the intermediate compounds $\mathbf{1}$ and $\mathbf{2}$ have been confirmed by our research group. The compound $\mathbf{2}$ when refluxed with hydrazine hydrate in ethanol medium led to the formation of parent compound 2-hydrazineyl-1-methyl-6-oxo-4(thiophen-2-yl)-1,6-dihydropyrimidine-5-carbonitrile (3) which was the key intermediate for the synthesis of target compounds 4a-d and 5a-g.

The IR spectrum of compound $\mathbf{3}$ exhibited stretching bands at 3,350, 2,220, and $1,670 \mathrm{~cm}^{-1}$ due to $\mathrm{NH}, \mathrm{CN}$, and $\mathrm{C}=\mathrm{O}$, respectively. ${ }^{1} \mathrm{H}$ NMR spectrum of parent compound 3 taken in DMSO exhibited multiplet at $\delta 8.2-7.2$ and singlet at $\delta 3.2$ toward three aromatic protons and $\mathrm{N}$-methyl protons, respectively. Two characteristic signals for $\mathrm{NH}$ and $\mathrm{NH}_{2}$ at $\delta 3.4$ and 2.4, respectively. The mass spectrum of the compound exhibited its molecular ion peak at $\mathrm{m} / \mathrm{z} 248$ corresponding to its molecular weight.

Intermediate compound $\mathbf{3}$ on acetylation with acetyl chloride in an acetic acid solvent for 8 hours refluxation led to the formation of $N^{\prime}$-[5-cyano-1-methyl-6-oxo-4-(thiophen-2-yl)-1,6dihydropyrimidin-2-yl] acetohydrazide (4a). The IR spectrum of compound 4a exhibited peaks at 3,074, 2,216, 1,679 $\mathrm{cm}^{-1}$ due to $\mathrm{NH}, \mathrm{CN}$, and $\mathrm{C}=\mathrm{O}$ groups, respectively. ${ }^{1} \mathrm{H}$ NMR spectrum of the same compound was recorded in DMSO, the multiplet observed at 7.3-8.3 corresponding to three aromatic protons, two NH protons appeared at 2.4 and $4.0, \mathrm{COCH}_{3}$ proton appeared at 2.6, and a singlet at 3.5 belongs to three protons of $N$-methyl. The structure of $4 \mathbf{a}$ was further confirmed by the appearance of a molecular ion peak at $\mathrm{m} / \mathrm{z}$ $290(\mathbf{M}+1)$ in its mass spectrum. Similarly, the compounds $\mathbf{4 b}-\mathbf{d}$ were prepared by using the corresponding acid chlorides.

The compound 3 was also refluxed with the benzaldehyde in ethanol with a catalytic amount of acetic acid for 12 hours to yield 2-[(2E)-2-benzylidenehydrazinyl]-1-methyl-6-oxo-4(thiophen-2-yl)-1,6-dihydropyrimidine-5-carbonitrile (5a). The IR spectrum of compound 5a exhibited peaks at 3,113, 2,224, 1,671 , and $1,551 \mathrm{~cm}^{-1}$ due to $\mathrm{NH}, \mathrm{CN}, \mathrm{C}=\mathrm{O}$, and $\mathrm{CH}=\mathrm{N}$ groups, respectively. ${ }^{1} \mathrm{H}$ NMR spectrum of the same compound recorded in DMSO, exhibited a peak at $\delta 3.4$ corresponding to one proton of amine, at $\delta 9.9$ for $\mathrm{CH}=\mathrm{N}$ proton, multiplet between $\delta 7.1$ and 8.5 corresponds to eight aromatic protons, singlet at 2.1 belongs to three protons of $\mathrm{N}-\mathrm{CH}_{3}$. The structure of $\mathbf{5 a}$ was further confirmed by the appearance of a molecular ion peak at $m / z 336(\mathrm{M}+1)$ in its mass spectrum. Similarly, compounds $\mathbf{5} \mathbf{b}-\mathbf{g}$ were prepared by using the corresponding aldehydes.

The detailed experimental procedure, analysis data for the compounds mentioned above have been incorporated in the experimental section. The structures of all the synthesized compounds have been elucidated by IR, ${ }^{1} \mathrm{H}$ NMR, LC-MS, and elemental analysis data. Some of the selected compounds have been tested for antibacterial, antifungal, and analgesic activities, and the results have been discussed.

\section{Pharmacology}

The tested compounds exhibited significant to moderate antibacterial activity (Table 2) compared to the standard drugs against all microorganisms. Compounds $\mathbf{4 a}$ and $\mathbf{5 b}$ showed significant antibacterial activity against all the bacterial strains. Compound 4a exhibited equipotent antifungal activity as that of a standard compound (Table 3). Compounds 5a and $\mathbf{5 b}$ showed considerable analgesic activity when compared to a standard substance (Table 4).

\section{CONCLUSION}

Reactions performed to achieve Schiff bases, and carboxamides of parent compound 2-hydrazineyl-1-methyl-6-oxo4-(thiophen-2-yl)-1,6-dihydropyrimidine-5-carbonitrile (3) were eco-friendly and yields obtained were satisfactory. Purification of the compounds was achieved by recrystallization method, and the purity was over $99 \%$ which was ascertained by Highperformance liquid chromatography (HPLC). Characterization of the compounds was completed by spectral analysis. Title compounds were screened for antibacterial, antifungal, and analgesic properties. Title compounds $\mathbf{4 a}$ and $\mathbf{5 b}$ showed significant antibacterial activity against all the bacterial strains. For antifungal activity, test compound $\mathbf{4 a}$ exhibited equipotent as that of standard compound. Title compounds $\mathbf{5} \mathbf{a}$ and $\mathbf{5 b}$ exhibited considerable analgesic activity when compared to a standard substance.

\section{ACKNOWLEDGMENT}

The authors would like to thank the Department of Chemistry, School of Basic Sciences, Rani Channamma University, National Research Foundation, South Africa and 
Durban University of Technology, South Africa, for support (96807 and 98884) and encouragement.

\section{FUNDING}

Nil.

\section{CONFLICTS OF INTEREST}

The authors declare that they have no conflict of interests.

\section{REFERENCES}

Amr AEG, Al-Omar MA, Abdalla MM. Pharmacological activity of some 2,6-bis(thieno[2,3-b]pyrimidine)pyridine derivatives as antiulcerogenic agents. J Comput Theor Nanosci, 2016; 13:7351-4.

Aruna Kumari M, Triloknadh S, Harikrishna N, Vijjulatha M, Venkata Rao C. Synthesis, antibacterial activity, and docking studies of 1,2,3-triazole-tagged thieno[2,3-d]pyrimidinone derivatives. J Heterocycl Chem, 2017; 54:3672-81.

Bairagi KM, Venugopala KN, Mondal PK, Gleiser RM, Chopra D, García D, Odhav B, Nayak SK. Larvicidal study of tetrahydropyrimidine scaffolds against Anopheles arabiensis and structural insight by single crystal X-ray studies. Chem Biol Drug Des, 2018; 92:1924-32.

Bari SB, Haswani NG. Design, synthesis and molecular docking study of thienopyrimidin-4(3H)-thiones as antifungal agents. J Saudi Chem Soc, 2017; 21:S264-74.

Borate HB, Annadate RA, Deokate SB. Preparation of thienopyrimidinone derivatives for use as antimycobacterial agents. Coun Sci Ind Res India, 2016; 56.

Bugge S, Buene AF, Jurisch-Yaksi N, Moen IU, Skjoensfjell EM, Sundby E, Hoff BH. Extended structure-activity study of thienopyrimidinebased EGFR inhibitors with evaluation of drug-like properties. Eur J Med Chem, 2016; 107:255-74.

Chandrashekharappa S, Venugopala KN, Nayak SK, Gleiser GR, García DA, Kumalo HM, Kulkarni RS, Mahomoodally FM, Venugopala R, Mohan MK, Odhav B. One-pot microwave assisted synthesis and structural elucidation of novel ethyl 3-substituted-7-methylindolizine-1-carboxylates with larvicidal activity against Anopheles arabiensis. J Mol Struct, 2018a; 1156:377-84.

Chandrashekharappa S, Venugopala KN, Tratrat C, Mahomoodally FM, Aldhubiab BE, Haroun M, Venugopala R, Mohan MK, Kulkarni RS, Attimarad MV, Harsha S, Odhav B. Efficient synthesis and characterization of novel indolizines: exploration of in vitro COX-2 inhibitory activity and molecular modelling studies. New J Chem, 2018b; 42:4893-901.

Chandrashekharappa S, Venugopala KN, Venugopala R, Padmashali B. Qualitative anti-tubercular activity of synthetic ethyl 7-acetyl-2-substituted-3-(4-substituted benzoyl) indolizine-1-carboxylate analogues. J Appl Pharm Sci, 2019; 9(02):124-8.

Devi K, Venugopala KN, Rao GK. Synthesis of substituted 3, 4-dihydropyrimidine-2(1H)-thiones and their biological activity. Ind J Het Chem, 2009; 18:305-6.

Dharma Rao BD, Bhandary S, Chopra D, Venugopala KN, Gleiser RM, Kasumbwe K, Odhav B. Synthesis and characterization of a novel series of 1,4-dihydropyridine analogues for larvicidal activity against Anopheles arabiensis. Chem Biol Drug Des, 2017; 90:397-405.

Ghith A, Ismail NSM, Youssef K, Abouzid KAM. Medicinal attributes of thienopyrimidine based scaffold targeting tyrosine kinases and their potential anticancer activities. Arch Pharm (Weinheim), 2017; 350.

Joshi A, Venugopala KN, Rao GK, Devi K, Pathak A. Synthesis of 3-[4-(6-bromo-2-oxo-2H-chromen-3-yl)-1,3-thiazol-2-yl]-2-(substituted phenyl) 1,3-thiazolidin-4-ones and their biological activity. Ind J Het Chem, 2011; 20:295-6.

Kankanala J, Kirby KA, Huber AD, Casey MC, Wilson DJ, Sarafianos SG, Wang Z. Design, synthesis and biological evaluations of N-Hydroxy thienopyrimidine-2,4-diones as inhibitors of HIV reverse transcriptase-associated RNase H. Eur J Med Chem, 2017; 141:149-61.
Klossowski S, Liu Y, Ren P, Feng J, Wu T, Li L, Pollock J, Borkin D, Cierpicki T, Grembecka J. Furo[2,3-d]pyrimidine and thieno[2,3-d] pyrimidine derivatives as composition inhibitors for the interaction of menin with MLL proteins and their preparation, pharmaceutical compositions and use in the treatment of diseases. Kura Oncology, Inc., The Regents of the University of Michigan, Ann Arbor, MI, 264 p, 2017.

Mallikarjuna SM, Sandeep C, Basavaraj P. Synthesis, antimicrobial activity of piperazin-1-yl (3,4,5-trimethoxyphenyl)methanone derivatives. Der Pharma Chem, 2016; 8:262-8.

Nagesh HK, Basavaraj P, Sandeep C, Musturappa TE, Lokesh MR. Synthesis and characterization of novel benzothiophene substituted oxadiazole derivatives and their antimicrobial activity. Der Pharma Chem, $2015 ; 7: 129-36$.

Nagesh HK, Basavaraj P, Sandeep C, Yuvaraj TCM, Siddesh MB, Mallikarjuna SM. Synthesis and antimicrobial activity of benzothiophene substituted coumarins, pyrimidines and pyrazole as new scaffold. Int J Pharm Sci Rev Res, 2014; 28:6-10.

Noravyan AS, Paronikyan EG, Sirakanyan SN, Akopyan SF. Synthesis and conversion of condensed thieno[2,3-d]- and thieno[3,2-d] pyrimidines. Hayastani Kim Handes, 2012; 65:447-73.

Ortikov IS, Turdibaev ZE, Islamova ZI, Elmuradov BZ, Abdurazakov AS, Bektemirov AM, Osipova SO, Khushbaktova ZA, Syrov VN, Shakhidoyatov KM. Search for Bactericides among derivatives of deoxyvasicinone, mackinazolinone, and thienopyrimidinones. Pharm Chem J, 2017; 51:456-64.

Pisal MM, Nawale LU, Patil MD, Bhansali SG, Gajbhiye JM, Sarkar D, Chavan SP, Borate HB. Hybrids of thienopyrimidinones and thiouracils as anti-tubercular agents: SAR and docking studies. Eur J Med Chem, 2017; 127:459-69.

Ram VJ, Vanden Berghe DA, Vlietinck AJ. Chemotherapeutical agents. V. Synthesis and activities of novel pyrimidines derived from 5-cyano-6-aryl-2-thiouracil. Liebigs Ann Chem, 1987; 797-801.

Ramesh B, Bhalgat CM. Novel dihydropyrimidines and its pyrazole derivatives: synthesis and pharmacological screening. Eur J Med Chem, 2011; 46:1882-91.

Ravez S, Arsenlis S, Barczyk A, Dupont A, Frederick R, Hesse S, Kirsch G, Depreux P, Goossens L. Synthesis and biological evaluation of di-aryl urea derivatives as c-Kit inhibitors. Bioorg Med Chem, 2015; 23:7340-7.

Rosado LA, Wahni K, Degiacomi G, Pedre B, Young D, de la Rubia AG, Boldrin F, Martens E, Marcos-Pascual L, Sancho-Vaello E, Albesa-Jove D, Provvedi R, Martin C, Makarov V, Versees W, Verniest G, Guerin ME, Mateos LM, Manganelli R, Messens J. The antibacterial prodrug activator Rv2466c is a mycothiol-dependent reductase in the oxidative stress response of Mycobacterium tuberculosis. J Biol Chem, 2017; 292:13097-110.

Sandeep C, Basavaraj P, Rashmi SK, Mallikarjuna SM, Siddesh MB, Nagesh HK., Thriveni KS. Synthesis of substituted 5-acetyl-3benzoylindolizine-1-carboxylate from substituted 2-acetyl pyridinium bromides. Het Lett, 2014; 4:371-6.

Sandeep C, Padmashali B, Kulkarni RS. Efficient synthesis of indolizines and new imidazo[1,2-a]pyridines via the expected cyclization of aromatic cycloimmonium ylides with electron deficient alkynes and ethyl cyanoformate. Tet Lett, 2013a; 54:6411-4.

Sandeep C, Padmashali B, Kulkarni RS. Synthesis of isomeric subtituted 6-acetyl-3-benzoylindolizine-1-carboxylate and 8-acetyl-3benzoylindolizine-1-carboxylate from subtituteded 3-acetyl pyridinium bromides and their antimicrobial activity. J Appl Chem, 2013b; 2:1049-56.

Sandeep C, Padmashali B, Venugopala KN, Kulkarni RS, Venugopala R, Odhav B. Synthesis and characterization of ethyl 7-acetyl2-substituted 3-(substituted benzoyl)indolizine-1-carboxylates for in vitro anticancer activity. Asian J Chem, 2016a; 28:1043-8.

Sandeep C, Venugopala KN, Gleiser RM, Chetram A, Padmashal B, Kulkarni RS, Venugopala R, Odhav B. Greener synthesis of indolizine analogues using water as a base and solvent: study for larvicidal activity against Anopheles arabiensis. Chem Biol Drug Des, 2016b; 88:899-904. 
Shishoo C, Ananthan S, Bhadti V, Ullas G, Chhabria M, Bariwal J, Venkatesh L, Nargund G, Jain K. Synthesis of pyrimidines and condensed pyrimidines through reactions of nitriles with o-aminocarbonyl substrates under acidic conditions. Heterocycles, 2009; 78:1627-65.

Siddesh MB, Basavaraj P, Thriveni KS, Sandeep C. Synthesis of polynuclear pyrimidine derivatives and their pharmacological activities. Heter Lett, 2014a; 4:503-14.

Siddesh MB, Basavaraj P, Thriveni KS, Sandeep C, Goudarshivnnanava BC. Synthesis and pharmacological evaluation of some novel pyrimidine derivatives. J Applicable Chem, 2013; 2:1281-8.

Siddesh MB, Padmashali B, Thriveni KS, Sandeep C. Synthesis of thiophene-linked pyrimidopyrimidines as pharmaceutical leads. J Chem Sci, 2014b; 126:821-6.

Srnivasula RVM, Mannem LB, Ratnam KG, Gokuladoss V, Yerramsetti VS. Thieno[2,3-d]pyrimidin-4(3H)-one compounds with antimycobacterial properties. Coun Sci Ind Res India, 2016; 56.

Teo T, Yang Y, Yu M, Basnet SKC, Gillam T, Hou J, Schmid RM, Kumarasiri M, Diab S, Albrecht H, Sykes MJ, Wang S. An integrated approach for discovery of highly potent and selective Mnk inhibitors: Screening, synthesis and SAR analysis. Eur J Med Chem, 2015; 103:53950.

Thriveni KS, Padmashali B, Siddesh MB, Sandeep C. Synthesis of Pyrimidine incorporated piperazine derivatives and their antimicrobial activity. Indian J Pharm Sci, 2014; 76:332-8.

Venugopala KN, Gleiser RM, Chalannavar KR, Odhav B. Antimosquito properties of 2-substituted phenyl/benzylamino-6-(4chlorophenyl)-5-methoxycarbonyl-4-methyl-3,6-dihydropyrimidin-1-ium chlorides against Anopheles arabiensis. Med Chem, 2014; 10:211-9.

Venugopala KN, Nayak SK, Pillay M, Prasanna R, Coovadia YM, Odhav B. Synthesis and antitubercular activity of 2-(substituted phenyl/benzyl-amino)-6-(4-chlorophenyl)-5-(methoxycarbonyl)-4methyl-3, 6-dihydropyrimidin-1-ium chlorides. Chem Biol Drug Des, 2013; 81:219-27.

Venugopala KN, Rao GD, Bhandary S, Pillay M, Chopra D, Aldhubiab BE, Attimarad M, Alwassil OI, Harsha S, Mlisana K. Design, synthesis, and characterization of (1-(4-aryl)-1H-1, 2, 3-triazol-4-yl) methyl, substituted phenyl-6-methyl-2-oxo-1, 2, 3, 4-tetrahydropyrimidine5-carboxylates against Mycobacterium tuberculosis. Drug Des Devel Ther, $2016 ; 10: 2681$
$\mathrm{Wu}$ YJ. Heterocycles and medicine: a survey of the heterocyclic drugs approved by the U.S. FDA from 2000 to present. Prog Heterocycl Chem, 2012; 24:1-53.

Yong J, Lu C, Wu X. Synthesis of Isoxazole moiety containing thieno[2,3-d]pyrimidine Derivatives and preliminarily in vitro anticancer activity (Part II). Anti-Cancer Agents Med Chem, 2015; 15:1148-55.

Zhang L, Wang ZY, Ding YJ. Synthesis and antitumor activity of fluorinated thieno-[2,3-d] pyrimidine derivatives containing 1,3,4-thiadiazole. Jingxi Huagong, 2015; 32:611-5.

Zhang Q, Zhang L, Yu J, Li H, He S, Tang W, Zuo J, Lu W. Discovery of new BTK inhibitors with B cell suppression activity bearing a 4,6-substituted thieno[3,2-d]pyrimidine scaffold. RSC Adv, 2017; 7 26060-9.

How to cite this article:

Padmashali B, Chidananda BN, Govindappa B, Basavaraj SM, Chandrashekharappa S, Venugopala KN. Synthesis and characterization of novel 1,6-dihydropyrimidine derivatives for their pharmacological properties. J Appl Pharm Sci, 2019; 9(05):117-124. 